\title{
Article \\ Mapping the Effects of Potassium on Fuel Conversion in Industrial-Scale Fluidized Bed Gasifiers and Combustors
}

\author{
Teresa Berdugo Vilches* ${ }^{\mathbb{D}}$, Jelena Maric, Henrik Thunman and Martin Seemann
}

check for

updates

Citation: Berdugo Vilches, T.; Maric, J.; Thunman, H.; Seemann, M.

Mapping the Effects of Potassium on Fuel Conversion in Industrial-Scale Fluidized Bed Gasifiers and Combustors. Catalysts 2021, 11, 1380. https://doi.org/10.3390/ catal11111380

Academic Editors: Pekka Simell and Matti Reinikainen

Received: 15 October 2021

Accepted: 13 November 2021

Published: 16 November 2021

Publisher's Note: MDPI stays neutral with regard to jurisdictional claims in published maps and institutional affiliations.

Copyright: (c) 2021 by the authors. Licensee MDPI, Basel, Switzerland. This article is an open access article distributed under the terms and conditions of the Creative Commons Attribution (CC BY) license (https:// creativecommons.org/licenses/by/ $4.0 /)$.
Division of Energy Technology, Department of Space, Earth, and Environment (SEE), Chalmers University of Technology, 41296 Gothenburg, Sweden; jelenam@chalmers.se (J.M.); henrik.thunman@chalmers.se (H.T.); martin.seemann@chalmers.se (M.S.)

* Correspondence: berdugo@chalmers.se
Abstract: Potassium $(\mathrm{K})$ is a notorious villain among the ash components found in the biomass, being the cause of bed agglomeration and contributing to fouling and corrosion. At the same time, $\mathrm{K}$ is known to have catalytic properties towards fuel conversion in combustion and gasification environments. Olivine (MgFe silicate) used as gasifier bed material has a higher propensity to form catalytically active $\mathrm{K}$ species than traditional silica sand beds, which tend to react with $\mathrm{K}$ to form stable and inactive silicates. In a dual fluidized bed (DFB) gasifier, many of those catalytic effects are expected to be relevant, given that the bed material becomes naturally enriched with ash elements from the fuel. However, a comprehensive overview of how enrichment of the bed with alkali affects fuel conversion in both parts of the DFB system is lacking. In this work, the effects of ash-enriched olivine on fuel conversion in the gasification and combustion parts of the process are mapped. The work is based on a dedicated experimental campaign in a Chalmers DFB gasifier, wherein enrichment of the bed material with $\mathrm{K}$ is promoted by the addition of a reaction partner, i.e., sulfur, which ensures $\mathrm{K}$ retention in the bed in forms other than inactive silicates. The choice of sulfur is based on its affinity for $\mathrm{K}$ under combustion conditions. The addition of sulfur proved to be an efficient strategy for capturing catalytic $\mathrm{K}$ in olivine particles. In the gasification part, K-loaded olivine enhanced the char gasification rate, decreased the tar concentration, and promoted the WGS equilibrium. In the combustion part, $\mathrm{K}$ prevented full oxidation of $\mathrm{CO}$, which could be mitigated by the addition of sulfur to the cyclone outlet.

Keywords: potassium; catalyst; dual fluidized bed; olivine; gasifier; combustor; tar; sulfur; combustion emissions

\section{Introduction}

Gasification of the biomass offers the possibility to reduce greenhouse gas (GHG) emissions and increase the share of renewable resources in different industrial sectors. Through gasification, the biomass is converted into an energy-rich gas (i.e., raw gas) that contains mainly $\mathrm{H}_{2}, \mathrm{CO}$, and $\mathrm{CO}_{2}$, with lower levels of $\mathrm{CH}_{4}$ and other hydrocarbons originating from the volatile fraction of the fuel. The net conversion process requires heat, and several gasifier configurations to achieve energy balance in different ways have been proposed and investigated. In a dual fluidized bed (DFB) reactor, the heat production and gasification reactions occur in two separate but interconnected fluidized bed reactors, i.e., the combustor and the gasifier. In the combustor, heat is generated through the combustion of the char and other residual streams produced in the gasification reactor. Thereafter, the heat is transported to the gasifier by means of a sand-like material that circulates continuously between the two reactors. The concept of the DFB gasifier has been successfully demonstrated in several projects [1-3].

Optimization of DFB gasification is mainly concerned with a high yield of gas with low tar content and a low heat demand for high energy efficiency. This optimization usually involves fine adjustment of the conversion rate in the gasifier so that the residual char and 
other streams can cover the heat demand without generating unwanted excess heat. In other words, to achieve high energy efficiency, the heat demand of the gasifier should be kept as low as possible while ensuring a sufficiently high conversion rate in the gasifier. A high conversion rate in the gasifier involves both char gasification reactions to produce $\mathrm{H}_{2}$ and $\mathrm{CO}$ and secondary reactions of the volatile fraction of the fuel to yield as much gas as possible via cracking and steam reforming. The behaviors of the heat demand and the fuel conversion rate in the gasifier regarding temperature are antithetical, requiring other means to speed up fuel conversion, such as catalyst-assisted gasification.

A general observation that has been made at commercial DFB gasification plants operating with the biomass is that over time, the gas yield and its quality increase when using olivine as the bed material [4,5]. This behavior has been attributed to the enrichment of olivine with catalytically active elements such as alkali and alkaline earth metals, which originate from the biomass ash or from additives. There is an ongoing debate as to the contributions of the different ash species to the catalytic effects observed and as to whether the catalytic effects are purely heterogeneous or homogeneous in nature. In this context, potassium $(\mathrm{K})$ and calcium $(\mathrm{Ca})$ are the most predominant species in the biomass ash that have been linked to the acquired catalytic activity of ash-enriched bed materials [5-7]. Calcium is most likely connected to heterogeneous catalytic effects given the solid nature of the Ca compounds formed under gasification and combustion conditions. Potassium, on the other hand, is linked to potential homogeneous gas phase interactions [8] given the gaseous nature of common $\mathrm{K}$ species detected at gasification and combustion temperatures, e.g., $\mathrm{K}, \mathrm{KOH}$, and $\mathrm{KCl}$. The focus of this work was on the role of $\mathrm{K}$ in the DFB configuration.

The increased catalytic activity of the bed material arising from ash accumulation is not valid for all types of systems. The effect of alkali on conversion of the fuel is dependent upon the physical and chemical availabilities of the $\mathrm{K}$ species, and these in turn depend on the nature of the bed material and the mode of interaction with the alkali. More specifically, if the alkali is bound to silicon in the form of a silicate, its catalytic availability is very limited and the catalytic activities are negligible $[9,10]$. Therefore, the catalytic effects discussed here apply to bed materials that contain only a small amount of available silicon in the matrix, e.g., olivine [1-3,5], bauxite [11], or feldspar [12,13], or to conditions under which the absorption capability of the usually applied silica-based sands is depleted. A similar reasoning is valid for the ash composition of the fuel where the use of a fuel with a high silicon-to-potassium ratio (S/K ratio) in the ash will lead to the formation of stable $\mathrm{K}$ silicates [14], and these will likely not show any of the aforementioned catalytic effects. For these reasons, the examples used in this work are based primarily on olivine as the bed material and biomasses with a composition that entails an excess of $\mathrm{K}$ with respect to the level of silicon.

Alkali species in a DFB system are known to be potential precursors of the conversion rate of the biomass. The catalytic activity of $\mathrm{K}$ was developed, for instance, for coal gasification in the 1980s, e.g., the Exxon process [15], where the main goal was to increase the char gasification rates. In a DFB system, the catalytic consequences of the availability and transport of alkali though the system are expected to go beyond the catalysis of char gasification. In the past few years, efforts have been made to distinguish specific catalytic effects and reactions that are altered by the presence of ash-enriched bed materials or alkali vapors. The effects of ash-enriched olivine on biomass conversion have been examined in relation to char gasification rates [16], gas quality [4,5,7], the water-gas shift (WGS) reaction [6], and the fuel burnout in the combustor [17]. The latter is rarely documented in the fluidized bed combustion literature. Marinkovic et al. found that the increase in activity of olivine in the gasification part coincided with insufficient $\mathrm{CO}$ burnout in the combustor [5]. This effect was related to the disruption of $\mathrm{CO}$ oxidation in the presence of $\mathrm{K}$. In a recent work, the inhibitory effect of $\mathrm{K}$ on $\mathrm{CO}$ oxidation was thoroughly investigated at the laboratory scale; it was found that $\mathrm{K}$ in the gas phase could remove $\mathrm{OH}$ radicals from the combustion environment, thereby preventing complete oxidation of CO [17]. 
Apart from the fragmented efforts to date to understand specific effects mediated by ash in DFB gasifiers, there has been no comprehensive description of the effect of alkali on fuel conversion in a large-scale DFB setup. The aim of this work was to fill that gap by presenting a comprehensive picture of the catalytic role of alkali in a DFB system, encompassing a gasification and combustion reactor. For this purpose, a dedicated experimental campaign at a Chalmers DFB gasifier is presented here, in which controlled enrichment of the bed with alkali was achieved through the addition of sulfur (S) to the bed material, while the composition of the flue gas and raw gas was monitored.

\subsection{Transport of K in DFB Systems and Enhanced Retention of K by Means of Sulfur Addition}

For materials that do not chemically retain alkali, the form of alkali in the reactor depends on the available reaction partners, such as S, carbon dioxide, steam, and chlorine, as well as the conditions prevailing in the system. This is especially relevant for a DFB system as the differing fluidization media, air and flue gases in the CFB part and steam in the $\mathrm{BFB}$, create distinct regions with oxidizing and reducing conditions. Figure 1 presents a schematic of the generic paths that K can take in the DFB. Potential paths for K include direct formation of K compounds in the solid form (GS1, CS1, in the gasifier or the combustor, respectively), which then follow the bed material stream; the release of $\mathrm{K}$ in the gaseous form (GG1, CG1), which follows the gas stream; the adsorption/absorption of K vapors to the bed material particles (GS2, CS2); and the release of K compounds from the bed material into the gas phase (GG2, CG2). Based on mass balance calculations, a net flow of $\mathrm{K}$ from the combustion part to the gasification part was measured at a Güssing plant [18], which points towards CS1, CS2, GG1, and GG2 being the predominant paths for K in DFB systems. This dynamic behavior of the bed material in retaining and releasing alkali under oxidizing and steam-rich conditions, respectively, is the same principle that is applied in flue gas treatment to remove alkali with solid absorbents [19].

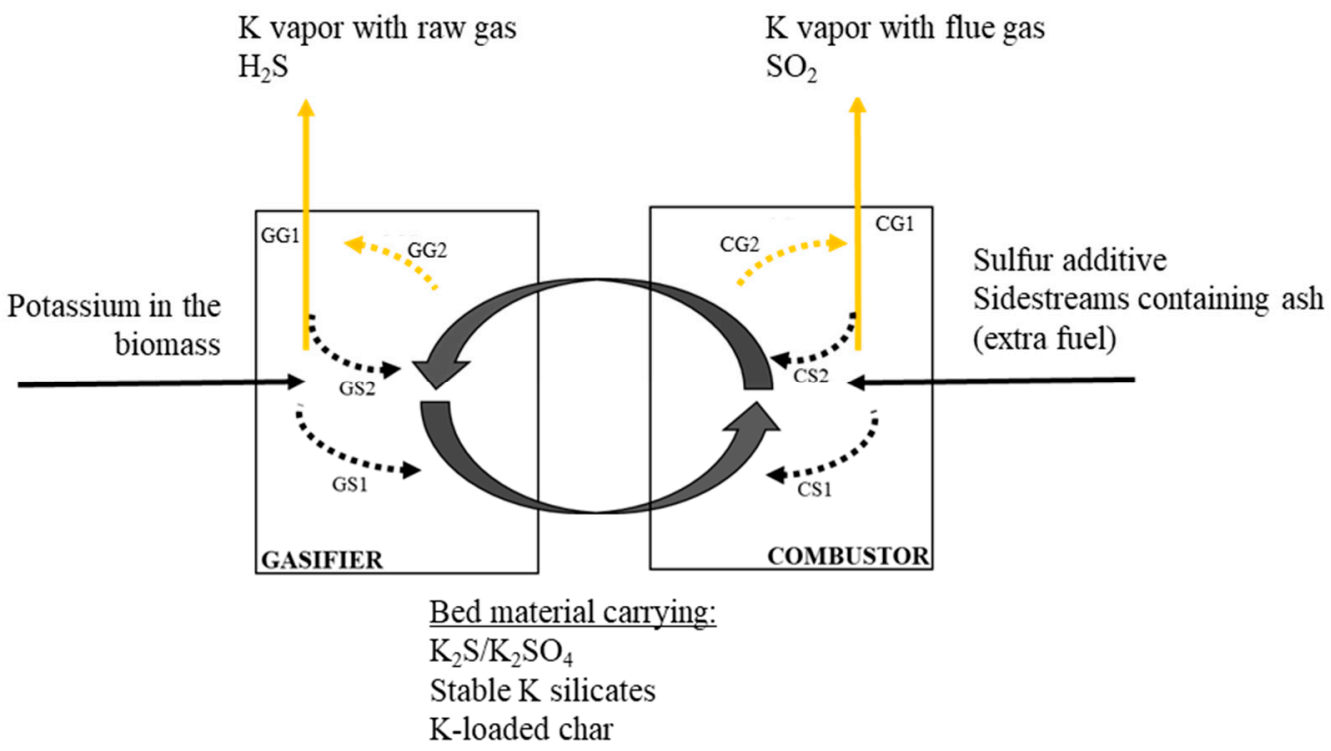

Figure 1. Transfer of alkali and sulfur-containing species between the reactors in a DFB system. G1, release of gaseous alkali from the fuel; G2, release of gaseous alkali from the bed material; S2, condensation of alkali vapors on bed material particles; S1, formation of solid alkali compounds; C, combustor; G, gasifier.

Potassium is typically released from the biomass in the forms of $\mathrm{KOH}$ and $\mathrm{K}$ and as $\mathrm{KCl}$ from chlorine-containing fuels [20]. The driving force for the transport of these $\mathrm{K}$ vapors via the GS2/CS2 paths is adsorption/absorption, such that the amount of K accumulated in the system is naturally limited by the equilibrium, the available surface, and the gas phase concentration. Providing a reaction partner such as $\mathrm{S}$ can further boost the net transport of $\mathrm{K}$ from the combustion to the gasification part by the bed material. 
In fact, $\mathrm{S}$ enhances the CS2 path by promoting formation of potassium sulfate $\left(\mathrm{K}_{2} \mathrm{SO}_{4}\right)$, which is retained in olivine particles [16]. This sulfation reaction has also been applied in other thermochemical processes, such as air and oxyfuel combustion, for reducing the concentrations of corrosive $\mathrm{KCl}$ in flue gas streams [21,22]. Therefore, $\mathrm{S}$ was selected here as a reaction partner for $\mathrm{K}$ based on its well-known affinity for this ash element under combustion conditions.

\subsection{The Chalmers DFB Plant}

The experiments presented here were conducted in a Chalmers DFB unit, which consists of a 12 MWth circulating fluidized bed (CFB) boiler and an integrated 2 MWth bubbling fluidized bed (BFB) gasifier [23], as schematized in Figure 2. As the plant serves as a heat production unit for the campus, heat is extracted from the CFB, which always requires fuel feeding to the boiler. The system can be operated in two different modes: (i) only the boiler and (ii) the boiler and the gasifier together. The switch between these two modes is facilitated by an intermediate vessel referred to as the particle distributor (No. 5 in Figure 2). The particle distributor returns the bed material directly to the boiler or, alternatively, it leads the bed material to the gasifier via a loop seal (No. 7 in Figure 2). When the gasifier is included in the loop, the bed material returns to the boiler via loop seal 2 (No. 8 in Figure 2). The raw gas produced in the gasifier is discharged into the boiler, where it is combusted.

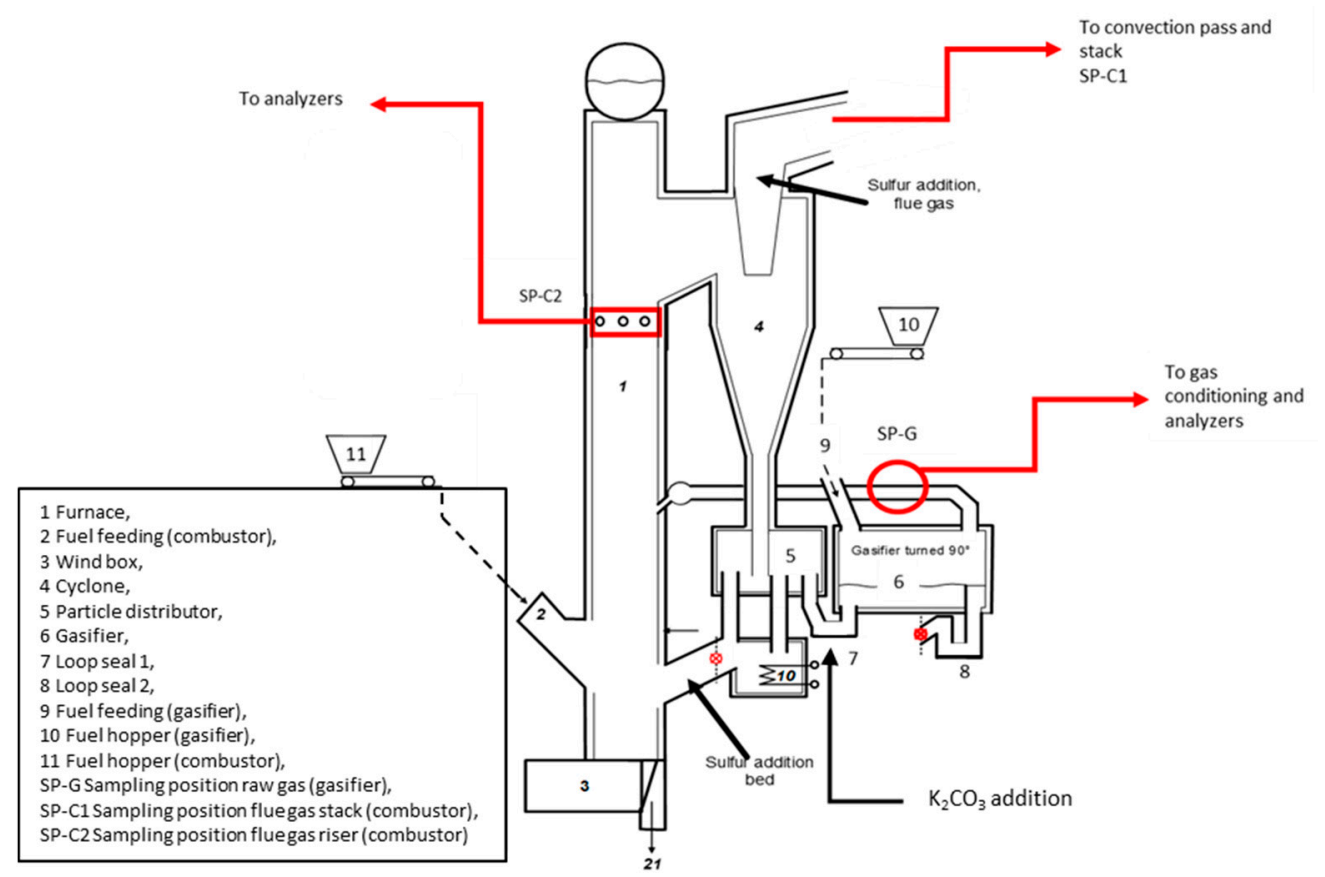

Figure 2. Schematic of the Chalmers DFB system, indicating the feeding scheme, the position for addition of $S$, and the gas sampling points.

Three main variables were investigated: (1) accumulation of fuel ash in the bed material; (2) deliberate addition of $S$ to the system; and (3) deliberate addition of potassium to the system. Ash accumulation in the system occurred naturally following the addition of fuel to the boiler (No. 2 in Figure 2) and the gasifier (No. 9 in Figure 2). S was introduced for selected time periods into the return leg of the bed material and to the boiler (indicated with a black arrow in Figure 2). This implies that $\mathrm{S}$ was first exposed to the oxidizing conditions of the boiler and subsequently transported to the gasifier if it was retained in olivine. A batch of $\mathrm{K}_{2} \mathrm{CO}_{3}$ was added to the gasifier on one occasion to investigate the direct influence of $\mathrm{K}$ on the raw gas quality. $\mathrm{K}_{2} \mathrm{CO}_{3}$ was introduced at the inlet loop seal to the gasifier (No. 7 in Figure 2). 
The results presented in this work pertain to the measurements carried out over 2 weeks of operation of the plant, with the focus on the first $65 \mathrm{~h}$ of continuous operation from start-up of the DFB. Additional tests with the boiler only were carried out thereafter. The results are interpreted in the context of the information derived from previous investigations conducted at the laboratory scale that addressed isolated catalytic aspects of S-K interactions in fuel conversion.

\section{Results}

An extract of selected operating parameters during the first $65 \mathrm{~h}$ of the campaign is shown in Figure 3, where the fuel feeding rates to the boiler and the gasifier as well as the addition of $\mathrm{S}$ and $\mathrm{K}_{2} \mathrm{CO}_{3}$ are detailed. During the measurements, process operation was kept as stable as possible unless a sharp transient was induced by the addition of $\mathrm{S}$ (red line in Figure 3) or by the addition of $\mathrm{K}_{2} \mathrm{CO}_{3}$ to the gasifier (black arrow in Figure 3). Transient periods were also connected to the switching of operation between cases with the boiler only and cases with both the gasifier and the boiler, as seen in Figure 3. In particular, the fuel flow to the boiler was adjusted when fuel was fed to the gasifier to maintain a similar energy input to the system for all the cases. Careful and controlled setting of the operational parameters was designed to ensure that the observed variations of the boiler emissions $\left(\mathrm{CO}\right.$ and $\left.\mathrm{SO}_{2}\right)$ and raw gas composition $\left(\mathrm{H}_{2} \mathrm{~S}, \mathrm{H}_{2}\right.$, and tar) could be attributed exclusively to the changes made to the bed properties.

Two runs with continuous feeding of wood pellets to the gasifier were conducted for approximately $10 \mathrm{~h}$ each (indicated by the orange shaded areas in Figure 3). During the first $65 \mathrm{~h}$ of operation, the effects of $\mathrm{K}$ and $\mathrm{S}$ on the boiler part were also noticeable. To confirm these observations made in the first $65 \mathrm{~h}$ of operation and investigate further the effects of $\mathrm{K}$ and $\mathrm{S}$ on combustion emissions, two additional experiments with the boiler only were carried out later in the campaign (not shown in Figure 3), as explained in Section 2.2. The gas measurements for the gasifier and the boiler parts are presented separately in Sections 2.1 and 2.2, respectively.

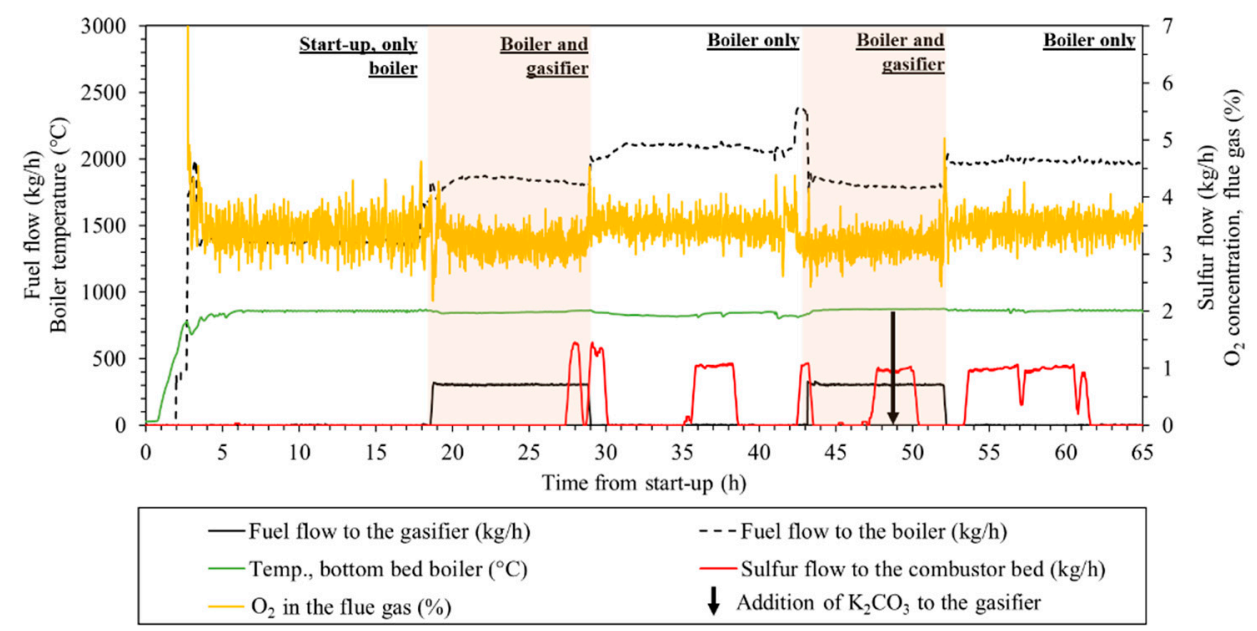

Figure 3. Overview of selected operating parameters of the Chalmers DFB system during the first $65 \mathrm{~h}$ of operation from start-up (i.e., time zero) with a bed of fresh olivine. The tests that included the gasifier are marked as "Boiler and gasifier".

Analysis of the bed material sample taken after $65 \mathrm{~h}$ of operation (Figure 4) confirmed accumulation of $\mathrm{S}$ and $\mathrm{K}$ in olivine particles. Potassium was stored in the regions with high concentrations of $S$, suggesting the formation of potassium sulfates or sulfides, which accords with previous observations [16]. The molar ratio of $\mathrm{K}$ to $\mathrm{S}$ in the SEM-EDX analysis was approximately one, indicating that other $\mathrm{S}$ compounds are expected to be present in the layer. 


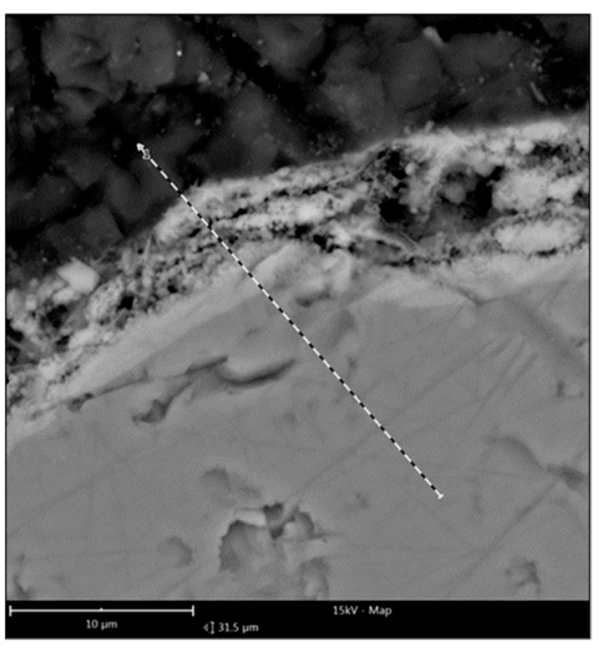

(a)

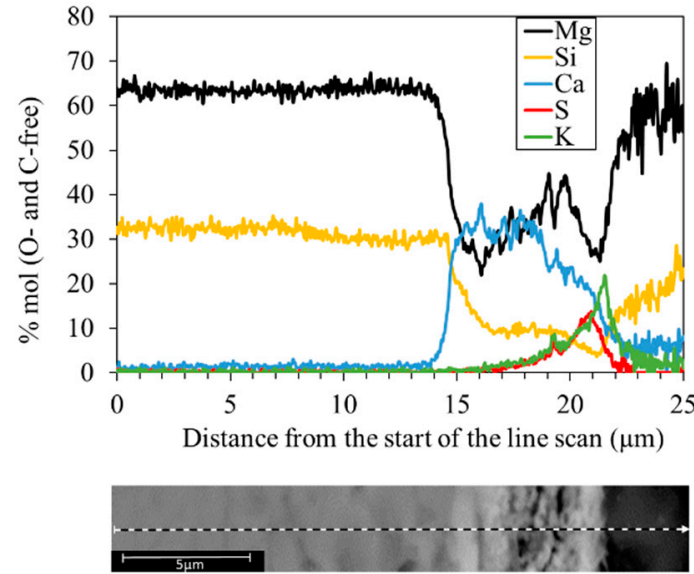

(b)

Figure 4. Line scan of the ash layer of an olivine particle. Sample taken at loop seal 1 (inlet to the gasifier) after the addition of elemental $S$ to the boiler. (a) SEM image with the indicated location of the selected line; the length of the analyzed line is $25 \mu \mathrm{m}$. (b) EDX analysis of the selected line. The line scan starts inside the particle and proceeds outwards.

\subsection{Gasifier}

The temperature of the gasifier bed was in the range of $800-810{ }^{\circ} \mathrm{C}$, the fluidization steam flow was $160 \mathrm{~kg} / \mathrm{h}$, and the fuel feeding rate was $300 \mathrm{~kg} / \mathrm{h}$. The first run with the gasifier (18-29 $\mathrm{h}$ after start-up) provided the reference gas composition before any addition of $S$ to the bed, as well as a measurement collected during the continuous feeding of $S$. In the second run with the gasifier (43-52 $\mathrm{h}$ after start-up), the bed had already been exposed to $S$ for several $h$. In this case, a reference measurement was made, and thereafter, transient measurements during $\mathrm{S}$ and $\mathrm{K}_{2} \mathrm{CO}_{3}$ addition were performed. The raw gas composition was monitored during that time; the concentrations of $\mathrm{H}_{2}$ and tar in the raw gas are summarized in Figure 5 for the two gasifier runs (indicated with orange shading in the figure). The concentrations of $\mathrm{H}_{2}$ and tar were selected as indicators of the catalytic activity of the bed material, i.e., higher catalytic activity is expected to yield a higher concentration of $\mathrm{H}_{2}$ and a lower concentration of tar.

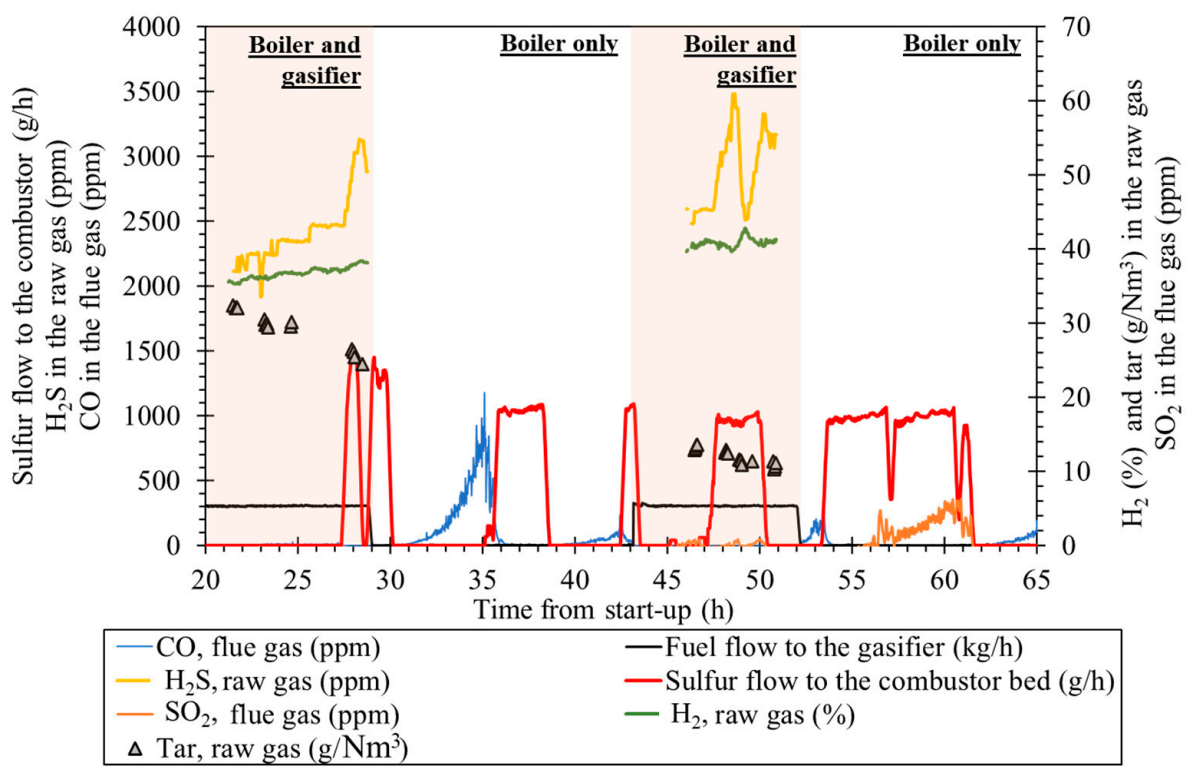

Figure 5. Influence of $\mathrm{S}$ addition on the concentrations of $\mathrm{H}_{2} \mathrm{~S}$, tar, and $\mathrm{H}_{2}$ in the raw gas (gasifier). 
The raw gas concentration before any addition of chemicals to the system was sampled $21 \mathrm{~h}$ after start-up of the DFB system. At that timepoint, approximately $100 \mathrm{~kg}$ of fuel ash had already entered the system. The raw gas showed a tar concentration of $32 \mathrm{~g} / \mathrm{Nm}^{3}$, $35.5 \% \mathrm{H}_{2}$, and $2300 \mathrm{ppm} \mathrm{H}_{2} \mathrm{~S}$. During the first few $\mathrm{h}$, the $\mathrm{H}_{2}$ and $\mathrm{H}_{2} \mathrm{~S}$ concentrations in the raw gas showed a slow and steady increase of $0.3 \% / \mathrm{h}$, in line with the enrichment of the bed with the fuel ash. The addition of $S$ to the bed at $t=27 \mathrm{~h}$ intensified the increase in $\mathrm{H}_{2}$ yield, as shown in Figure 6. The increase in the $\mathrm{H}_{2}$ yield was followed by an increase in the yield of $\mathrm{CO}_{2}$ and a decrease in the $\mathrm{CO}$ yield, in line with the WGS reaction equilibrium. The yields of $\mathrm{CH}_{4}$ and tar also decreased during the addition of $\mathrm{S}$, reflecting the enhanced reforming reactions. In addition to the increased catalytic activity towards tar and the WGS reaction, the results show an increased char gasification rate with the addition of S. Based on the carbon balance calculations over the gasifier, the char gasification rate was estimated to be $6 \%$ at the reference measurement at $\mathrm{t}=21 \mathrm{~h}$, and it increased to approximately $19 \%$ during the feeding of $S$ at $t=28 \mathrm{~h}$.

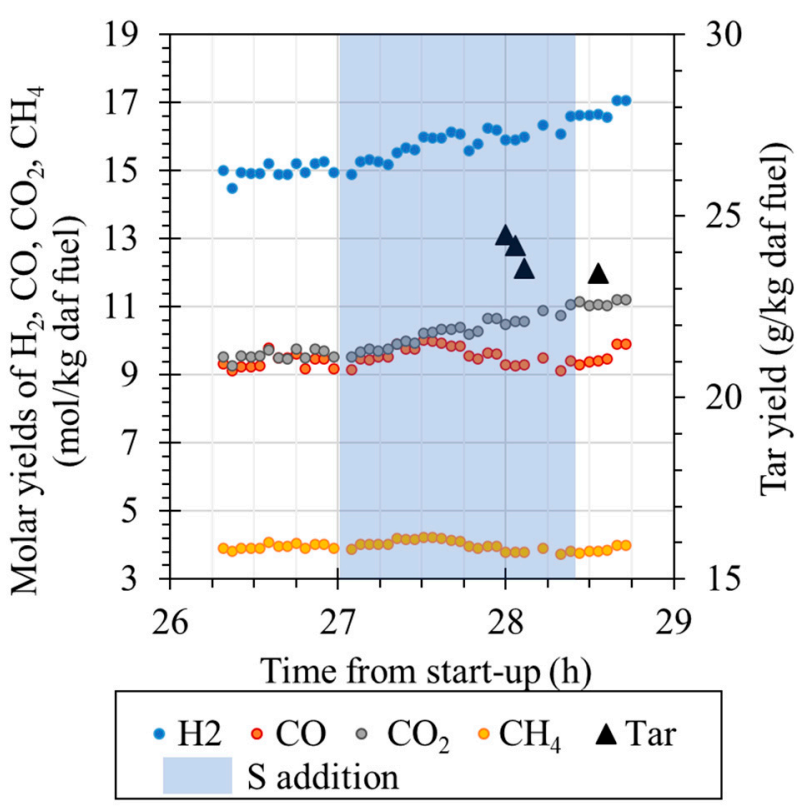

Figure 6. Yields of $\mathrm{H}_{2}, \mathrm{CO}, \mathrm{CO}_{2}, \mathrm{CH}_{4}$, and tar obtained in the gasifier during the first continuous addition of $\mathrm{S}$ to the boiler bed.

In the second run carried out in the gasifier, the tar yield was even lower and the yield of $\mathrm{H}_{2}$ increased further, indicating an activated olivine bed. By that point, the bed had been exposed to $14 \mathrm{~kg}$ of $\mathrm{S}$ granules and the raw gas contained $2600 \mathrm{ppm}_{2} \mathrm{~S}$, which was $13 \%$ higher that the initial conditions measured before any $S$ addition to the DFB. The raw gas contained $40.5 \% \mathrm{H}_{2}$ and $13 \mathrm{~g} / \mathrm{Nm}^{3}$ of tar, which was roughly $60 \%$ lower than the tar concentration measured before any addition of $S$ to the bed $(t=21 \mathrm{~h})$.

Before proceeding with the addition of $\mathrm{K}_{2} \mathrm{CO}_{3}$ to the gasifier, the flow of $\mathrm{S}$ was initiated. This resulted in a sharp increase in the level of $\mathrm{H}_{2} \mathrm{~S}$ in the raw gas similar to that obtained at $\mathrm{t}=28 \mathrm{~h}$. A moderate decrease in tar concentration followed the addition of $S$, such that it was $5 \%$ lower than before starting the $S$ flow. It was noticeable that the effect of $S$ on the tar concentration was less prominent this time, which can be attributed to the fact that the system had a high $\mathrm{S} / \mathrm{K}$ ratio by that point. The addition of $\mathrm{K}_{2} \mathrm{CO}_{3}$ at $\mathrm{t}=49 \mathrm{~h}$ caused a sudden drop in the $\mathrm{H}_{2} \mathrm{~S}$ concentration and a sharp increase in the concentration of $\mathrm{H}_{2}$ in the raw gas, as shown in Figure $5(\mathrm{t}=49 \mathrm{~h})$. The concentration of tar decreased by an additional $10 \%$ (relative to before the addition of $S$ and $\mathrm{K}_{2} \mathrm{CO}_{3}$ ), reaching $11 \mathrm{~g} / \mathrm{Nm}^{3}$.

In Figure 7, the tar results obtained during this campaign are compared with those obtained in the previous experiments with olivine, where the activation of olivine was carried out exclusively with the ash introduced by the fuel [5]. The addition of S clearly 
accelerated and intensified the catalytic activation process. Naphthalene was chosen for this comparison as it is among the most accurately measured species in the tar fraction given its large share and high retention in the SPA columns applied in both campaigns.

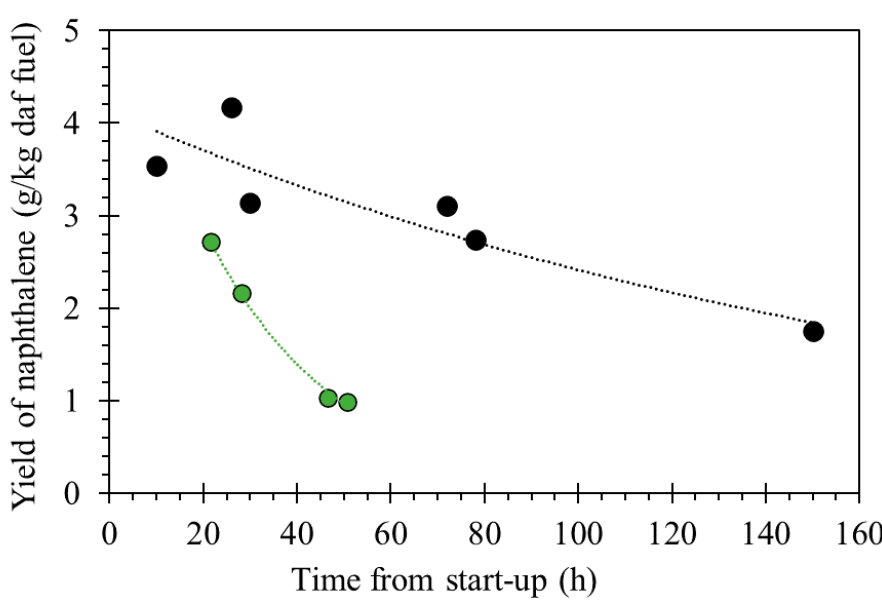

- Olivine (no additives) O Olivine (sulfur addition)

Figure 7. Comparison of activation levels of olivine (assessed as yields of naphthalene from the process) in the Chalmers DFB gasifier operating with the biomass with and without addition of sulfur to the bed.

\subsection{Boiler}

As shown in Figure 3, the effects on the $\mathrm{CO}$ and $\mathrm{SO}_{2}$ emissions in the boiler part were initially observed during the first $65 \mathrm{~h}$ of the campaign and in parallel with the gasifier runs described above. The boiler temperature was in the range of $840-860^{\circ} \mathrm{C}$ and the fuel feeding rate 1.7-2.0 tonnes/h. The air supply to the boiler was adjusted so that the oxygen concentration at the stack was stable in the range of 3.0-3.5\% (yellow line in the figure).

During the first $31 \mathrm{~h}$ of operation, the flue gases from the boiler were free of $\mathrm{SO}_{2}$ and $\mathrm{CO}$ emissions. One $\mathrm{h}$ after the $\mathrm{S}$ flow to the bed stopped, the $\mathrm{CO}$ concentration in the flue gases started to ramp up steadily. When the concentration of $\mathrm{CO}$ reached approximately $1100 \mathrm{ppm}$ at $\mathrm{t}=36 \mathrm{~h}$, the feeding of $\mathrm{S}$ to the bed was restarted, and the $\mathrm{CO}$ emissions started to decrease after a few min, reaching zero after approximately $1 \mathrm{~h}$ (Figure 5). A similar response pattern was obtained in the period $t=39-43 \mathrm{~h}$, i.e., the $\mathrm{CO}$ emissions from the boiler started to ramp up when the feeding of $S$ to the bed was interrupted. In this case, $S$ feeding was reinitiated as soon as the $\mathrm{CO}$ emissions exceeded $120 \mathrm{ppm}$. Remarkably, the $\mathrm{SO}_{2}$ emissions from the boiler were still zero despite the extensive exposure of the system to $\mathrm{S}$. After $51 \mathrm{~h}$ of operation and the addition of approximately $24 \mathrm{~kg}$ of elemental $\mathrm{S}$ to the system, the $\mathrm{SO}_{2}$ concentration started to rise steadily, reaching $7 \mathrm{ppm}$. The concentration of $\mathrm{SO}_{2}$ declined rapidly to zero when $\mathrm{S}$ feeding was discontinued at $\mathrm{t}=62 \mathrm{~h}$.

\subsubsection{Additional Test with Sulfur Feeding to the Bed}

In the first additional test, a similar experiment with $\mathrm{S}$ fed to the boiler bed was reproduced. The concentrations of $\mathrm{O}_{2}, \mathrm{CO}$, and $\mathrm{SO}_{2}$ were investigated at two different sampling positions: at the stack (SP-C1 in Figure 2) and over the cross-section of the riser of the boiler (SP-C2 in Figure 2). More details about the measurement are given in Section 4.5. The $\mathrm{O}_{2}, \mathrm{CO}$, and $\mathrm{SO}_{2}$ concentrations at the stack are shown in Figure 8, and the flue gas concentration at the riser of the combustor is shown in Figure 9.

This addition of S was carried out from $t=241 \mathrm{~h}$ to $t=244 \mathrm{~h}$. Note that in the days preceding this experiment, 10 tonnes of the bed material had been replaced with unused olivine, yet the bed inventory was expected to behave as activated olivine given the extensive addition of $\mathrm{S}$ to the bed over the same period. The average $\mathrm{CO}$ concentration before $\mathrm{S}$ feeding was around $150 \mathrm{ppm}$ and the $\mathrm{SO}_{2}$ concentration was zero ppm. The 
$\mathrm{CO}$ emissions started to decrease approximately $10 \mathrm{~min}$ after the $\mathrm{S}$ addition started and declined to zero after $30 \mathrm{~min}$.

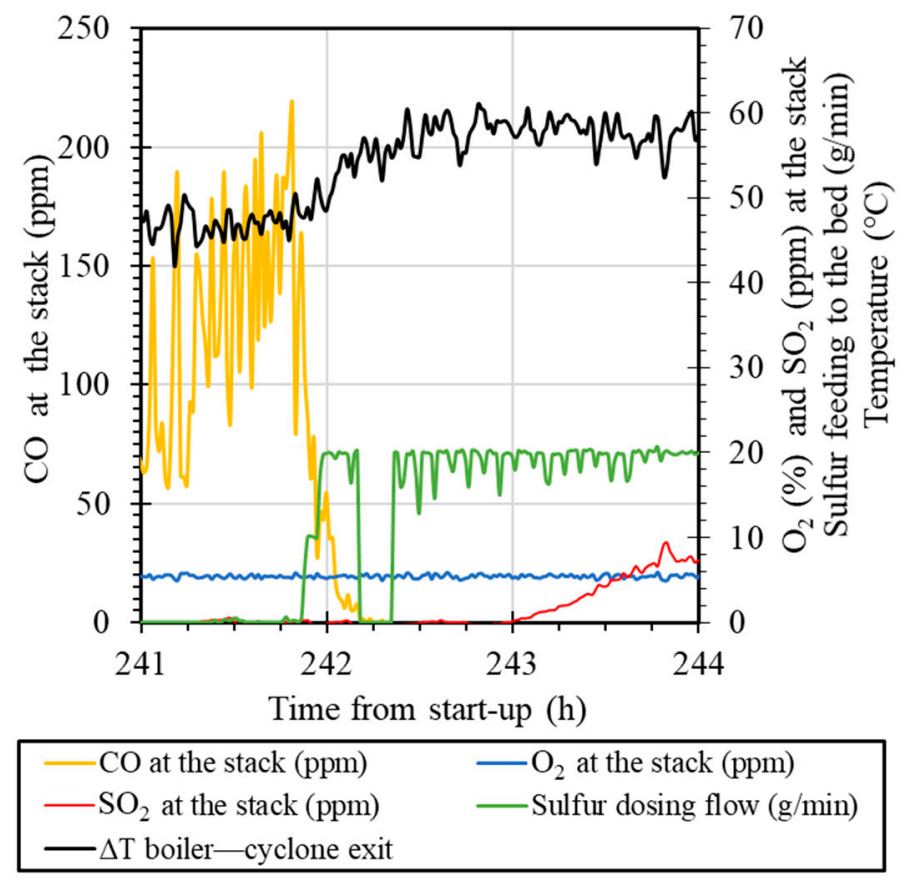

Figure 8. $\mathrm{SO}_{2}$ and $\mathrm{CO}$ concentrations (in ppm) in the chimney vs. the time from start-up.

The $\mathrm{SO}_{2}$ emissions at the stack started to increase 60-70 min after the addition of $\mathrm{S}$ started, as shown in Figure 8. Considering the bed inventory of 3.5 tonnes and an average circulation time for the sand particles in the system of $8-12 \mathrm{~min}$, this is a reasonable response time to (a) give all the K-loaded particles a chance to encounter $S$ and (b) reach a level of $S$ that is sufficiently high to generate excess $S$ in the system leaving through the cyclone. This response time also supports the notion that the bed was already active and loaded with $\mathrm{S}$, such that the response time of $\mathrm{SO}_{2}$ was much shorter than that observed at the beginning of the campaign.

Inside the combustor, the trends obtained for the concentrations of $\mathrm{SO}_{2}, \mathrm{O}_{2}$, and $\mathrm{CO}$ are consistent with those observed at the stack. The concentrations measured at the riser (SP-C2 in Figure 2) before and during the addition of S are shown in Figure 9b-d. For this measurement, the cross-section of the combustion chamber was divided virtually into six cells, as shown in Figure 9a, and the measurements were carried out over the three cells at the centerline. The concentration profile of $\mathrm{CO}$ was $0.1-1.0 \%$ along the centerline of the combustor before starting the addition of $S(t=241 \mathrm{~h})$, which was 10-100 times higher than the concentration of $\mathrm{CO}$ at the stack. The concentration of $\mathrm{CO}$ at the riser decreased when $\mathrm{S}$ was added, while the $\mathrm{SO}_{2}$ concentration increased. Furthermore, at the stack, the $\mathrm{SO}_{2}$ concentration increased as the addition of $S$ proceeded between $t=42$ and $t=243 \mathrm{~h}$, while the $\mathrm{CO}$ concentration stabilized. The $\mathrm{O}_{2}$ concentration profile remained unaltered also inside the combustor, which further supports the idea that the changes in $\mathrm{CO}$ concentration are due to the chemical reactions rather than the distribution of oxygen.

Note that as S promotes the full conversion of $\mathrm{CO}$ inside the boiler, less combustion of unburnt species is expected at the cyclone position. This is in agreement with the change in the temperature distribution in the boiler where the temperature of the combustor increased while the temperature at the cyclone exit decreased correspondingly. As shown in Figure 8, the difference in temperature between the combustor and the cyclone increased to $15^{\circ} \mathrm{C}$ during the time period that the $\mathrm{CO}$ emissions decreased to zero and stabilized there. 


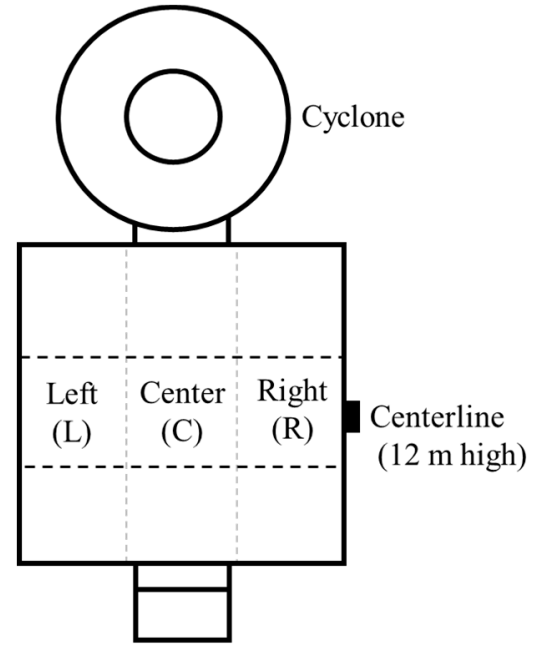

Boiler fuel feeding system

(a)

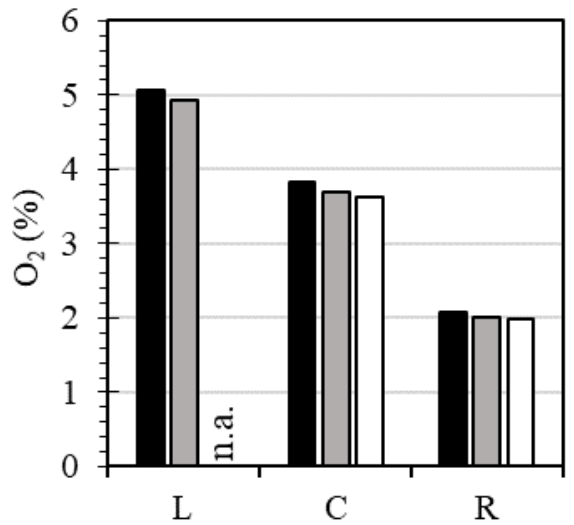

(c)

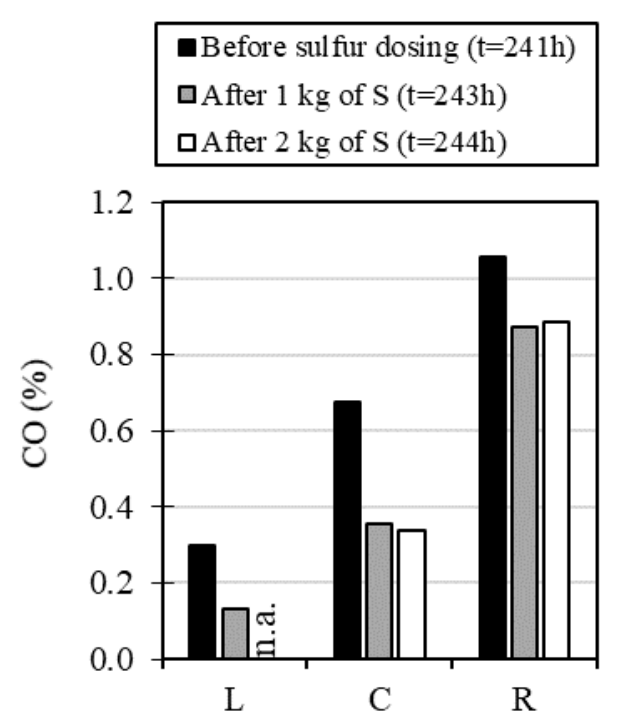

(b)

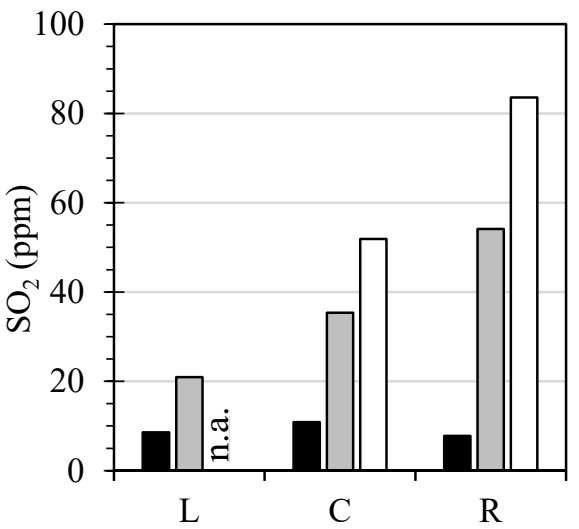

(d)

Figure 9. Measurements over the cross-section of the riser of the combustor at a height of $12 \mathrm{~m}$ from the fluidization nozzles before and during the addition of sulfur granulates to the boiler bed. (a) Schematic of the cross-section and locations of the measurement points in the centerline; (b) CO concentration (\%vol); (c) $\mathrm{O}_{2}$ concentration (\%vol); and (d) $\mathrm{SO}_{2}$ concentration (\%vol). The term "n.a." indicates that the measurement was not available.

\subsubsection{Additional Test with Sulfur Feeding to the Cyclone}

The second additional test with the boiler consisted only of the addition of three batches of $85 \mathrm{~g}$ of $S$ granulates to the flue gas leaving the cyclone at the position indicated with a black arrow in Figure 2. This test aimed to elucidate whether the reactions observed could occur in the gas phase without mediation by the bed material particles. The flue gas composition was measured continuously at the stack during the addition of S.

As shown in Figure 10, three batches of S (black dotted line) were added when the $\mathrm{CO}$ concentration at the stack started to increase steadily from $100 \mathrm{ppm}$ to $700 \mathrm{ppm}$. The three batches showed a similar response pattern: a peak drop of the $\mathrm{CO}$ concentration at the stack reaching $0 \%$ in 2-3 min, followed by a peak of $\mathrm{SO}_{2}$ of approximately $80 \mathrm{ppm}$. This test confirmed the interaction between $\mathrm{S}, \mathrm{K}$, and the combustion chemistry that can be expected in the gas phase. 


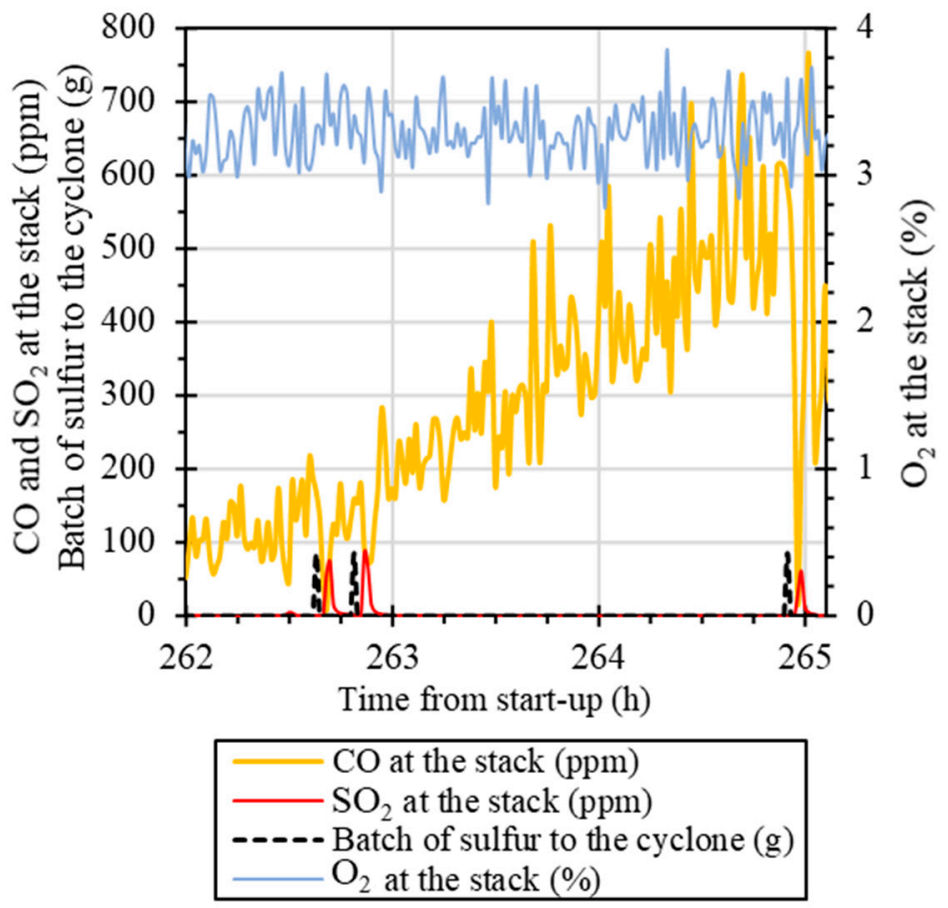

Figure 10. $\mathrm{CO}$ and $\mathrm{SO}_{2}$ concentrations in the flue gases at the stack and the effects of addition of three batches of $85 \mathrm{~g}$ of elemental sulfur to the flue gas exiting the cyclone.

\section{Discussion: Behavior of Potassium and Sulfur in a DFB System}

The addition of $\mathrm{S}$ proved to be a good strategy for promoting retention of $\mathrm{K}$ in the bed. In other words, the addition of $S$ favored the CS2 route (recall Figure 1) without requiring higher partial pressures of $\mathrm{KOH}$ in the combustor to load the particles with K. Sulfur added by the fuel or artificially was, therefore, expected to be bound as sulfates to olivine particles, e.g., as $\mathrm{K}_{2} \mathrm{SO}_{4}$ (in line with the bed material analysis in Figure 4), or released in the gasifier as predominantly $\mathrm{H}_{2} \mathrm{~S}$, as shown in Figure 5. In fact, the $\mathrm{H}_{2} \mathrm{~S}$ concentration of the raw gas at the beginning of the campaign was already 13-fold higher than the level of $\mathrm{H}_{2} \mathrm{~S}$ that the $\mathrm{S}$ content of the wood pellets fed into the gasifier could generate. This further confirms that $\mathrm{S}$ was transported from the boiler to the gasifier even with the natural input of ash with the biomass. The release of $\mathrm{S}$ in the gasifier in the form of $\mathrm{H}_{2} \mathrm{~S}$ in an $\mathrm{H}_{2}$-rich atmosphere is in agreement with the thermodynamic calculations presented previously [5].

In the boiler part, $\mathrm{CO}$ and $\mathrm{SO}_{2}$ emissions did not appear during the first $30 \mathrm{~h}$ and $55 \mathrm{~h}$, respectively. This time delay in the emissions is also in line with the idea of an accumulation process. At the beginning of the campaign, a share of $\mathrm{K}$ is released from the biomass fed to the boiler part, as well as from the char coming from the gasifier. $\mathrm{K}$ is first expected to react partially with the silicon in the biomass ash and olivine. Considering the bed material composition, roughly $30 \%$ of $\mathrm{SiO}_{2}$ in the bed material can be expected to be readily available for further reactions with alkali and alkaline earth metals, whereas $70 \%$ of $\mathrm{SiO}_{2}$ is mostly present as $\mathrm{Mg}_{2} \mathrm{SiO}_{4}$ (fosterite) in the material in its initial state. This share of $\mathrm{K}$ is expected to be bound chemically to the material in the form of $\mathrm{K}$ silicate, which means that it is stable under all conditions prevailing in the DFB system. Indeed, as the concentration of free silicon to react in olivine is limited, this chemical reaction of $\mathrm{K}$ with the bed material is expected to be negligible after some $\mathrm{h}$ of operation, although it is highly relevant for the start-up with unused olivine.

After the free silicon in olivine is depleted by conversion into stable silicates, it is more likely that $\mathrm{K}$ from the fuel is released and remains in the forms of $\mathrm{KOH}$ and $\mathrm{K}_{2} \mathrm{CO}_{3}$ in the boiler (CG1) and predominantly as $\mathrm{KOH}$ (GG1) in the gasifier. The high catalytic activity of the bed material in the gasifier and the parallel increase of $\mathrm{CO}$ emissions in the boiler part can be explained by the presence of reactive gaseous $\mathrm{K}$ in the system. In the boiler, it 
is noteworthy that during the entire campaign, the $\mathrm{O}_{2}$ concentration is sufficient for the complete combustion of the fuel at the temperature ranges applied. Yet, $\mathrm{CO}$ emissions clearly increase as olivine loses its capacity to bind $\mathrm{K}$ in a permanent manner. This trend is well in line with the inhibition of $\mathrm{CO}$ combustion by gaseous $\mathrm{KOH}$ as investigated under laboratory conditions [17], as well as with the sulfation route presented in the context of corrosion mitigation [22]. In fact, even the addition of $S$ at the exit of the cyclone, as shown in Figure 10, proved to be adequate to promote the full conversion of $\mathrm{CO}$ in an atmosphere that is rich in $\mathrm{K}$ species.

In the gasification chamber, the results presented in Figure 5 confirm that the enrichment of the olivine bed with $\mathrm{K}$ and other ash elements promotes catalytic activity of the bed material towards char, tar, and the WGS reaction. Relating the catalytic activity to the expected release of $\mathrm{KOH}[5,10]$ is more complicated, although some evidence can be derived from the results presented here. On the one hand, the capability of the bed material to catalyze char gasification indirectly confirms that there is release of gaseous $\mathrm{K}$ from ashloaded particles into the gasification environment [16]. On the other hand, the enrichment of particles with reactive $\mathrm{K}$ shown here clearly enhances the catalytic properties of the bed as compared to the reference activation campaign without additives (recall the comparison in Figure 7). This supports the notion that $\mathrm{K}$ is a key element in the observed catalytic processes. Furthermore, direct addition of $\mathrm{K}_{2} \mathrm{CO}_{3}$ to the gasifier and the rapid response obtained in terms of the raw gas composition suggest that $\mathrm{K}$ in the gas phase can catalyze reactions involving biomass-derived volatiles. The response of the tar concentration to the addition of $\mathrm{K}_{2} \mathrm{CO}_{3}$ into the gasifier was fast, albeit somewhat mild. Here, it should be noted that the catalytic activity in the gasifier was already at the highest level observed in the Chalmers gasifier at that point, as shown in Figure 7. Therefore, it is speculated that a saturation effect may have been reached and no further influence on tar yield could be achieved by the addition of alkali to the system.

The results presented here confirm previous results obtained on a large scale that connect the activation process of olivine to the accumulation of ash elements in the bed $[2,4,6,7]$, and we emphasize here the role of $\mathrm{K}$ in such catalytic activation. While it is difficult to distinguish between heterogeneous and homogeneous catalytic effects, the results suggest that both are important. Some homogeneous catalytic effects in line with the experimental results presented here involve the WGS reaction, inhibition of $\mathrm{CO}$ combustion, and tar reactions. In the context of combustion, a recent investigation [17] confirmed that gaseous $\mathrm{K}$ influences the pool of radicals through a mechanism that reflects the responses in $\mathrm{CO}$ concentration obtained here. Similar mechanistic investigations of the potential effect of gas phase alkali on the pool of radicals created in a steam gasification environment are currently lacking. Understanding these mechanisms would elucidate the fast and potent effect of $\mathrm{K}$ on the $\mathrm{H}_{2}$ concentration shown here, as well as the roles of alkali in tar formation, steam reforming, and secondary cracking reactions.

\section{Materials and Methods}

\subsection{Bed Material}

The bed material applied in the experimental campaign was olivine of Norwegian origin (provided by Sibelco) and had the following composition: $41.7 \% \mathrm{SiO}_{2}, 49.6 \% \mathrm{MgO}$, $7.4 \% \mathrm{Fe}_{2} \mathrm{O}_{3}, 0.46 \% \mathrm{Al}_{2} \mathrm{O}_{3}, 0.31 \% \mathrm{Cr}_{2} \mathrm{O}_{3}$, and $0.32 \% \mathrm{NiO}$. The bed inventory in the DFB weighed approximately 3.5 tonnes.

A bed material sample was taken from the inlet loop seal of the gasifier at $t=65 \mathrm{~h}$ to confirm the accumulation of $\mathrm{K}$ in the bed material particles. The sample was mounted on epoxy and polished to reveal the cross-section of the particle. The specimen was then analyzed by SEM-EDS. Tabletop Phenom ProX and Quanta 200 FEG scanning electron microscopes equipped with an Oxford energy-dispersive spectrometer (EDS) were applied. 


\subsection{Fuels}

The composition of the wood pellets and wood chips fed to the gasifier and the boiler, respectively, are listed in Table 1. The fuel was analyzed by the Swedish Research Institute (RISE) using standard methods SS-EN-ISO 1648, 1694, and 18,122. The moisture content was analyzed in-house by drying the samples at $105^{\circ} \mathrm{C}$ for $24 \mathrm{~h}$ in an oven and measuring the weight difference.

Table 1. Elemental analysis of the fuels used in the boiler and the gasifier.

\begin{tabular}{|c|c|c|}
\hline & Wood Chips (Boiler) & Wood Pellets (Gasifier) \\
\hline $\mathrm{C}(\mathrm{wt} \%$ dry $)$ & 50.2 & 50.5 \\
\hline $\mathrm{H}(\mathrm{wt} \%$ dry) & 6.0 & 6.1 \\
\hline $\mathrm{O}(\mathrm{wt} \%$ dry) & 43.0 & 43.0 \\
\hline $\mathrm{N}(w \mathrm{t} \%$ dry) & 0.115 & 0.065 \\
\hline $\mathrm{S}$ (wt \% dry) & 0.02 & 0.02 \\
\hline Moisture (wt \%) & 38.1 & 8.1 \\
\hline Ash (wt\% dry) & 0.53 & 0.43 \\
\hline $\mathrm{Al}$ (wt\% in the ash) & 0.36 & 1.16 \\
\hline $\mathrm{Si}(\mathrm{wt} \%$ in the ash) & 1.42 & 3.66 \\
\hline $\mathrm{Fe}(\mathrm{wt} \%$ in the ash) & 0.36 & 1.05 \\
\hline $\mathrm{Ti}$ (wt $\%$ in the ash) & 0.03 & 0.05 \\
\hline Mn (wt\% in the ash) & 1.23 & 2.84 \\
\hline $\mathrm{Mg}$ (wt\% in the ash) & 4.00 & 3.83 \\
\hline $\mathrm{Ca}$ (wt\% in the ash) & 22.28 & 21.91 \\
\hline $\mathrm{Ba}(\mathrm{wt} \%$ in the ash) & 0.26 & 0.32 \\
\hline $\mathrm{Na}$ (wt\% in the ash) & 0.74 & 0.52 \\
\hline $\mathrm{K}$ (wt\% in the ash) & 13.43 & 10.22 \\
\hline $\mathrm{P}(\mathrm{wt} \%$ in the ash) & 1.50 & 1.47 \\
\hline
\end{tabular}

\subsection{Additives}

Elemental $\mathrm{S}$ was introduced in the granular form in all the cases. The system for continuous feeding of $S$ into the bed consisted of a weighted hopper and a screw feeder, through which the granulated $\mathrm{S}$ was pneumatically transported. $\mathrm{S}$ was applied at feeding rates in the range of $1.0-1.5 \mathrm{~kg} / \mathrm{h}$, and the feeding position was at the combustor part in the return leg from the particle distributor to the boiler, as indicated with an arrow in Figure 2.

The batches of $S$ introduced at the cyclone position were added with a probe that contained a pre-weighed batch of $85 \mathrm{~g}$ of $\mathrm{S}$ granulates (see Figure 11). The probe was inserted into a dedicated port and it was turned upside down to discharge its content.

$\mathrm{K}_{2} \mathrm{CO}_{3}$ was introduced in the powder from, and it was dosed with a screw feeder and transported pneumatically into the inlet loop seal to the gasifier (No. 7 in Figure 2). In total, $6 \mathrm{~kg}$ of $\mathrm{K}_{2} \mathrm{CO}_{3}$ were added to the system over a period of $30 \mathrm{~min}$. 


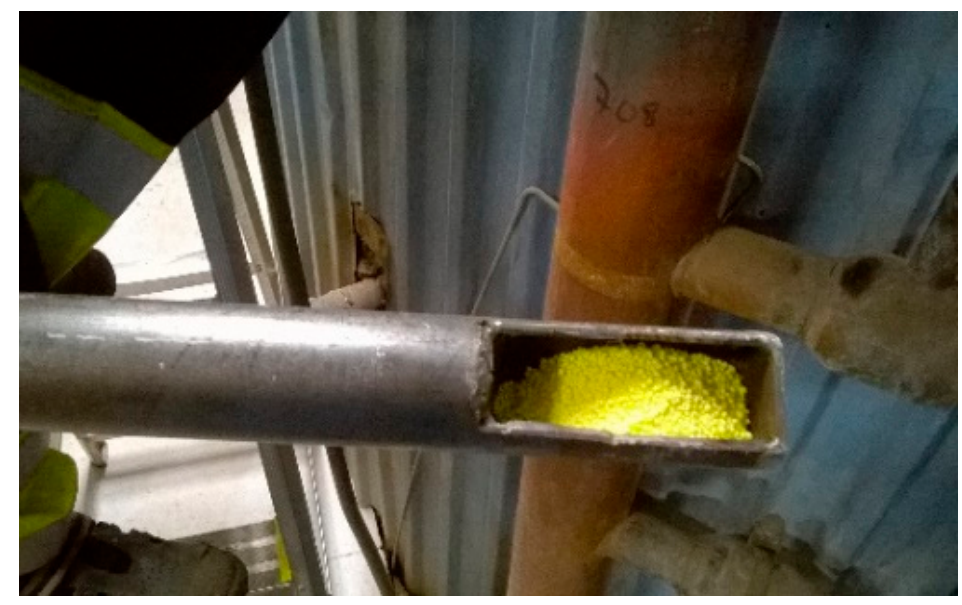

Figure 11. Batch probe for addition of sulfur granulates to the flue gas stream leaving the cyclone.

\subsection{Raw Gas Sampling}

To characterize the raw gas composition, a slipstream of the raw gas was acquired at the position indicated in Figure 2. The permanent gas components $\mathrm{H}_{2}, \mathrm{CO}, \mathrm{CO}_{2}, \mathrm{CH}_{4}, \mathrm{C}_{2}$, $\mathrm{C}_{3}, \mathrm{H}_{2} \mathrm{~S}$ were analyzed continuously in a Varian CP-4900 micro-GC equipped with two channels that use $\mathrm{He}$ and $\mathrm{Ar}$ as carrier gases, respectively. A known flow of He was fed to the gasifier as a tracer to quantify the total flow of the dry gases generated. Prior to the analysis of the permanent gas composition, the raw gas was filtered through a hot ceramic filter, cooled, and scrubbed in isopropanol to remove tar.

Tar sampling was performed using solid-phase extraction columns following the method described previously [24]. The column with the sample was eluted with a solvent and the resulting liquid sample was analyzed in a BRUKER 430 GC-FID using $\mathrm{H}_{2}$ as the carrier gas. This analysis covered aromatic compounds with boiling points between those of benzene and coronene. Three repeat analyses were carried out per sample collected, and the results shown are the average of the values obtained in the three-repeat analysis.

The estimation of char conversion was based on a separate measurement of the total carbon in the gas. A high-temperature reactor (HTR) was used in this case to steam reform a slipstream from the gasifier at $1700{ }^{\circ} \mathrm{C}$, so the raw gas was fully converted to permanent gases and readily measurable in a micro-GC. The system and carbon balance were described in detail previously [25].

\subsection{Flue Gas Sampling}

The concentrations of $\mathrm{O}_{2}, \mathrm{CO}$, and $\mathrm{SO}_{2}$ in the flue gases were measured continuously at the stack throughout the campaign to comply with emissions regulations. The flue gas was led through a heated line into a condenser to remove the water content and through a filter to remove particles before analysis in an NGA 2000 gas analyzer.

For the measurements over the cross-section of the combustor, the flue gas was sampled using a dedicated probe that was placed temporarily at the sampling point of interest (see Figure 12). The probe was water-cooled and equipped with a particle filter at the tip. The flue gas was extracted through a gas pump and led to the analyzer via a heated line. The gas was sampled and assayed continuously for $\mathrm{CO}, \mathrm{O}_{2}$, and $\mathrm{SO}_{2}$ in the NGA 2000 analyzer. The measurement was performed from one cell of the centerline at a time for $10 \mathrm{~min}$, respectively, until completing the centerline. 


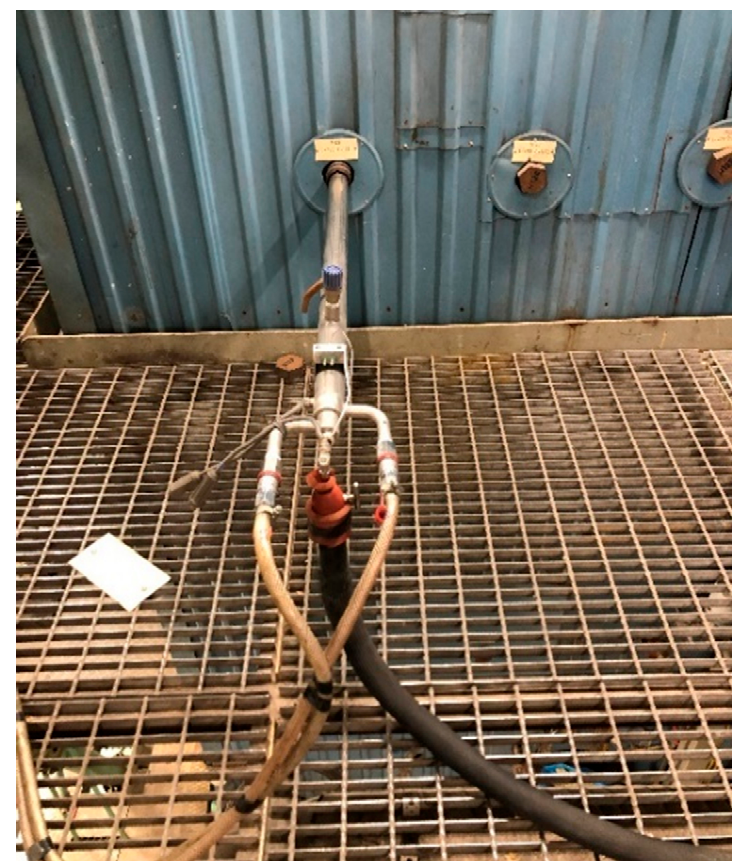

Figure 12. Flue gas sampling probe applied in the measurements performed over the cross-section of the combustor.

\section{Conclusions}

Understanding the behavior of catalytic $\mathrm{K}$ in DFB gasification is crucial for the design and operation of plants in an optimal manner, as well as for facilitating fuel flexibility. Despite the problematic role of alkali in causing agglomeration and corrosion, there exists a tremendous potential to enhance fuel conversion, with associated consequences for the combustion part. The reaction partner of $\mathrm{K}$ determines its behavior in the system, and $\mathrm{S}$ was the reaction partner investigated in this work. The following conclusions are derived from this work:

- In the gasifier, the catalytic activity of the bed is increased, leading to a lower concentration of tar, enhanced WGS reaction, and increased char gasification rate.

- Sulfur behaves as an effective reaction partner for potassium to enhance the storage of $\mathrm{K}$ in the bed material under combustion conditions and the consequent transport of $\mathrm{K}$ to the gasifier in a catalytically active form.

- In the combustion environment, $\mathrm{K}$ in the gas phase inhibits the complete conversion of $\mathrm{CO}$ at temperatures relevant to fluidized bed operation, i.e., around $900{ }^{\circ} \mathrm{C}$.

- The sulfation of alkali in the gas phase is an effective strategy to prevent $\mathrm{K}$ from inhibiting the complete $\mathrm{CO}$ oxidation.

Initial mechanistic insights into the interaction between $\mathrm{K}, \mathrm{CO}$, and $\mathrm{S}$ and the radical pool in the combustion environment at temperatures relevant to the fluidized bed have recently been described in the literature [17]. The influence of gaseous $\mathrm{K}$ on the radical pools generated in the steam gasification environment remains to be investigated at a mechanistic level.

Author Contributions: Conceptualization, T.B.V., J.M., H.T. and M.S.; methodology, T.B.V., M.S., J.M, H.T.; formal analysis, T.B.V. and J.M.; investigation T.B.V., M.S., J.M.; resources M.S. and H.T.; writing-original draft preparation T.B.V. and M.S.; writing—review and editing, M.S., J.M., H.T.; visualization, T.B.V.; project administration, M.S. and H.T.; funding acquisition, M.S. and H.T. All authors have read and agreed to the published version of the manuscript.

Funding: This work is the result of a long cooperation supported by Göteborg Energi AB, Akademiska Hus, the Swedish Energy Agency, and Valmet AB. Funding was received through the Swedish Gasi- 
fication Center (SFC) and from the European Union's Seventh program for research, technological development, and demonstration under grant agreement 321477 (BioProGReSs).

Acknowledgments: The authors acknowledge the research engineers Jessica Bohwalli, Johannes Öhlin and Rustan Hvitt for their technical support on the implementation, as well as the operators of Akademisca Hus for the operation of the DFB plant.

Conflicts of Interest: The authors declare no conflict of interest.

\section{References}

1. Thunman, H.; Seemann, M.; Berdugo Vilches, T.; Maric, J.; Pallares, D.; Ström, H.; Berndes, G.; Knutsson, P.; Larsson, A.; Breitholtz, C.; et al. Advanced biofuel production via gasification-lessons learned from 200 man-years of research activity with Chalmers' research gasifier and the GoBiGas demonstration plant. Energy Sci. Eng. 2018, 6, 6-34. [CrossRef]

2. Kuba, M.; He, H.; Kirnbauer, F.; Boström, D.; Öhman, M.; Hofbauer, H. Deposit build-up and ash behavior in dual fluid bed steam gasification of logging residues in an industrial power plant. Fuel Process. Technol. 2015, 139, 33-41. [CrossRef]

3. Kuba, M.; He, H.; Kirnbauer, F.; Skoglund, N.; Boström, D.; Öhman, M.; Hofbauer, H. Mechanism of Layer Formation on Olivine Bed Particles in Industrial-Scale Dual Fluid Bed Gasification of Wood. Energy Fuels 2016, 30, 7410-7418. [CrossRef]

4. Larsson, A.; Kuba, M.; Berdugo Vilches, T.; Seemann, M.; Hofbauer, H.; Thunman, H. Steam gasification of biomass-Typical gas quality and operational strategies derived from industrial-scale plants. Fuel Process. Technol. 2021, 212, 106609. [CrossRef]

5. Marinkovic, J.; Thunman, H.; Knutsson, P.; Seemann, M. Characteristics of olivine as a bed material in an indirect biomass gasifier. Chem. Eng. J. 2015, 279, 555-566. [CrossRef]

6. Kuba, M.; Havlik, F.; Kirnbauer, F.; Hofbauer, H. Influence of bed material coatings on the water-gas-shift reaction and steam reforming of toluene as tar model compound of biomass gasification. Biomass Bioenergy 2016, 89, 40-49. [CrossRef]

7. Kuba, M.; Kirnbauer, F.; Hofbauer, H. Influence of coated olivine on the conversion of intermediate products from decomposition of biomass tars during gasification. Biomass Convers. Biorefin. 2017, 7, 11-21. [CrossRef]

8. Yu, J.; Guo, Q.; Gong, Y.; Ding, L.; Wang, J.; Yu, G. A review of the effects of alkali and alkaline earth metal species on biomass gasification. Fuel Process. Technol. 2021, 214, 106723. [CrossRef]

9. Berdugo Vilches, T.; Marinkovic, J.; Seemann, M.; Thunman, H. Comparing Active Bed Materials in a Dual Fluidized Bed Biomass Gasifier: Olivine, Bauxite, Quartz-Sand, and Ilmenite. Energy Fuels 2016, 30, 4848-4857. [CrossRef]

10. Knutsson, P.; Maric, J.; Knutsson, J.; Larsson, A.; Breitholtz, C.; Seemann, M. Potassium speciation and distribution for the K2CO3 additive-induced activation/deactivation of olivine during gasification of woody biomass. Appl. Energy 2019, 248, 538-544. [CrossRef]

11. Marinkovic, J.; Seemann, M.; Schwebel, G.L.; Thunman, H. Impact of Biomass Ash-Bauxite Bed Interactions on an Indirect Biomass Gasifier. Energy Fuels 2016, 30, 4044-4052. [CrossRef]

12. Berguerand, N.; Berdugo Vilches, T. Alkali-Feldspar as a Catalyst for Biomass Gasification in a 2-MW Indirect Gasifier. Energy Fuels 2017, 31, 1583-1592. [CrossRef]

13. He, H.; Skoglund, N.; Öhman, M. Time-Dependent Layer Formation on K-Feldspar Bed Particles during Fluidized Bed Combustion of Woody Fuels. Energy Fuels 2017, 31, 12848-12856. [CrossRef]

14. Zhao, H.; Wakil, M.A.; Viljanen, J.; Song, Q.; Yao, Q.; Kwong, C.W.; Alwahabi, Z.T. In Situ Measurement of Potassium Release during Biomass Combustion Using Laser-Induced Breakdown Spectroscopy: Effect of Silicate on Potassium Release. Energy Fuels 2020, 34, 3262-3271. [CrossRef]

15. Nahas, N. Exxon catalytic coal gasification process: Fundamentals to flowsheets. Fuel 1983, 62, 239-241. [CrossRef]

16. Berdugo Vilches, T.; Maric, J.; Knutsson, P.; Rosenfeld, D.C.; Thunman, H.; Seemann, M. Bed material as a catalyst for char gasification: The case of ash-coated olivine activated by K and S addition. Fuel 2018, 224, 85-93. [CrossRef]

17. Berdugo Vilches, T.; Weng, W.; Glarborg, P.; Li, Z.; Thunman, H.; Seemann, M. Shedding light on the governing mechanisms for insufficient $\mathrm{CO}$ and $\mathrm{H} 2$ burnout in the presence of potassium, chlorine and sulfur. Fuel 2020, 273, 117762. [CrossRef]

18. Kirnbauer, F.; Koch, M.; Koch, R.; Aichernig, C.; Hofbauer, H. Behavior of Inorganic Matter in a Dual Fluidized Steam Gasification Plant. Energy Fuels 2013, 27, 3316-3331. [CrossRef]

19. Punjak, W.A.; Uberoi, M.; Shadman, F. High-temperature adsorption of alkali vapors on solid sorbents. AIChE J. 1989, 35, 1186-1194. [CrossRef]

20. Knudsen, J.N.; Jensen, P.A.; Dam-Johansen, K. Transformation and Release to the Gas Phase of Cl, K, and S during Combustion of Annual Biomass. Energy Fuels 2004, 18, 1385-1399. [CrossRef]

21. Allgurén, T.; Andersson, K. Chemical Interactions between Potassium, Sulfur, Chlorine, and Carbon Monoxide in Air and Oxy-fuel Atmospheres. Energy Fuels 2020, 34, 900-906. [CrossRef]

22. Weng, W.; Chen, S.; Wu, H.; Glarborg, P.; Li, Z. Optical investigation of gas-phase $\mathrm{KCl} / \mathrm{KOH}$ sulfation in post flame conditions. Fuel 2018, 224, 461-468. [CrossRef]

23. Larsson, A.; Seemann, M.; Neves, D.; Thunman, H. Evaluation of Performance of Industrial-Scale Dual Fluidized Bed Gasifiers Using the Chalmers 2-4-MWth Gasifier. Energy Fuels 2013, 27, 6665-6680. [CrossRef] 
24. Israelsson, M.; Seemann, M.; Thunman, H. Assessment of the Solid-Phase Adsorption Method for Sampling Biomass-Derived Tar in Industrial Environments. Energy Fuels 2013, 27, 7569-7578. [CrossRef]

25. Israelsson, M.; Larsson, A.; Thunman, H. Online Measurement of Elemental Yields, Oxygen Transport, Condensable Compounds, and Heating Values in Gasification Systems. Energy Fuels 2014, 28, 5892-5901. [CrossRef] 